\title{
Article
}

Arq Neuropsiquiatr 2011;69(6):932-937

\section{Thermal record of the test tubes method used for small fibers assessment}

\author{
Denny D. Collina, Manoel F. Villarroel, Carlos Julio Tierra-Criollo
}

\begin{abstract}
In Brazil, the test that uses test tubes filled with cold water $\left(25^{\circ} \mathrm{C}\right)$ and tubes filled with water heated to a temperature of $45^{\circ} \mathrm{C}$ is recommended by the Ministry of Health as a way of evaluate thermal sensitivity on the injured skin of leprosy patients. The purpose of this work was to quantify the thermal stimulation applied to the skin, as well as the temperature variation of the heated water and of the tube's outer surface during stimulation sessions. The experiment had the participation of 14 healthy volunteers (31.2 \pm 11.4 years-old), ten of which were male ( $33.1 \pm 13.5$ years-old) and four were female ( $26.5 \pm 4.7$ years-old). Three consecutive stimulation sessions were carried out, each of them with four stimuli. The maximum skin temperature at the end of the stimuli was measured at $35.8 \pm 0.6^{\circ} \mathrm{C}$. Such temperature values may be useful in the assessment of the loss of small fibers, which are responsible for the sensation of warmth.
\end{abstract}

Key words: leprosy, thermal sensation, thermal sensory testing.

Registro térmico do método dos tubos de ensaio aplicado na avaliação de fibras finas

\section{RESUMO}

No Brasil, o teste que utiliza tubos de ensaio preenchidos com água aquecida $\left(45^{\circ} \mathrm{C}\right)$ e resfriada $\left(25^{\circ} \mathrm{C}\right)$ é preconizado pelo Ministério da Saúde como forma de avaliar a sensibilidade térmica nas lesões de pele de pacientes com hanseníase. O objetivo deste trabalho foi quantificar o estímulo térmico na pele e a variação das temperaturas da água aquecida e da superfície externa do tubo, durante as sessões de estimulação. $O$ experimento contou com 14 voluntários saudáveis $(31,2 \pm 11,4$ anos), sendo dez do gênero masculino (33,1 $\pm 13,5$ anos) e quatro do gênero feminino ( $26,5 \pm 4,7$ anos). Realizaram-se três sessões seguidas de estimulação com quatro estímulos em cada sessão. A temperatura registrada na pele, ao final dos estímulos, apresentou diferenças entre as sessões, atingindo o máximo de $35,8 \pm 0,6^{\circ} \mathrm{C}$. Estes valores de temperatura podem ser úteis na avaliação da perda de fibras finas responsáveis pela sensação de aquecimento. Palavras-Chave: hanseníase, sensibilidade térmica, teste de sensibilidade térmica.

\section{Correspondence}

Carlos Julio Tierra-Criollo

Laboratório de Engenharia Biomédica

Programa de Pós-Graduação

em Engenharia Elétrica

Universidade Federal de Minas Gerais

Av. Antônio Carlos 6627

31270-901 Belo Horizonte MG - Brasil

E-mail: carjulio@cpdee.ufmg.br

Support

FAPEMIG, CAPES, CNPq e CEFET-MG

Received 22 December 2010

Received in final form 26 July 2011

Accepted 02 August 2011
The research on thermal sensitivity is performed, many times, by using test tubes filled with heated and cold water ${ }^{1}$. In Brazil, such test is recommended by the Ministry of Health ${ }^{2-4}$ for the evaluation of thermal sensitivity and, therefore, of small fibers present in the skin of leprosy patients. The test consists in using two test tubes filled with water, both of them with the temperature well defined, one containing water at $25^{\circ} \mathrm{C}^{5}$ and the other containing water heated to the temperature of $45^{\circ} \mathrm{C}$. Such temperature, according to the Ministry's manual ${ }^{2-4}$, must not exceed $45^{\circ} \mathrm{C}$, because, if it does, a sensation of heat pain may be produced, instead of warmth. The tubes must be placed on the patient's healthy skin, as well as on the suspect area, taking turns (each turn with two seconds of duration), at random, 
between hot and cold tubes. The patient, then, must identify whether the tube is cold or hot.

Despite the recommendation for a fixed-temperature test, some factors seem to contradict that assumption. One of them is the heat exchange between the water and the environment (through convection and radiation), or between the water and the examiner's or tested individual's skin (conduction), which leads either to the heating of the cold water or to the cooling of the heated water, since bodies kept at different temperatures tend to reach thermal equilibrium ${ }^{6,7}$. Another factor is the temperature difference between the tube's outer surface and the water that it contains, caused by the glass' low thermal conductivity ${ }^{6}$.

For this work, only water at $45^{\circ} \mathrm{C}$ was used. The main purpose was to quantify the thermal stimulation applied to the skin, in a controlled environment and using the same method, as well as the temperature variation for the water and for the tube's outer surface in stimulation sessions of healthy individuals.

\section{METHOD}

The experiment had the participation of 14 healthy volunteers with the age of $31.2 \pm 11.4$ (mean \pm S.D.) yearsold, ten of which were male ( $33.1 \pm 13.5$ years-old) and four were female (26.5 \pm 4.7 years-old). The study was approved by the local Ethics Committee, and all volunteers signed a "free and clarified" consent term.

The experiment's main purpose was to quantify the thermal stimulation applied to the skin, thus only heated water was used, considering that the heat transfer module between two bodies depends only on the temperature difference and on the physical properties of the bodies involved. Also, heat always flows from the hotter to the colder body ${ }^{6}$. The use of cold water is, therefore, unnecessary, because a similar result would be produced.

Three consecutive stimulation sessions were carried out on each volunteer, all performed by the same individual, in a silent environment, and room temperature adjusted to $26 \pm 1^{\circ} \mathrm{C}$. The stimulation time was two seconds (S2) for the first session, as recommended by the Brazilian Ministry of Health. A second session (S5, duration of five seconds), as well as a third one (S10, duration of ten seconds), were included in this study with the purpose of assessing how the three temperatures (water, tube's outer surface and skin) vary as stimulation time increases. Four stimuli were used per session, with a fixed five seconds interval between each stimulus. The interval between each session was of five minutes.

A common glass test tube, $180 \mathrm{~mm}$ long, internal diameter of $13.2 \mathrm{~mm}$, wall thickness of $1.0 \mathrm{~mm}$ and capacity of $24 \mathrm{~mL}$ was used for the stimuli (Fig 1). For each session it was filled with $15 \mathrm{~mL}$ of water, heated to a tem- perature of $70^{\circ} \mathrm{C}$, and held by the examiner near the open extremity between the first and second fingers. The tube was manually and constantly agitated while the water temperature was monitored. The test began when the temperature reached $45 \pm 0.5^{\circ} \mathrm{C}$. The temperatures were recorded for ten seconds, prior to the first stimulus, with the purpose of measuring the skin's initial temperature.

Temperature measurements were performed with the use of three NTC thermistor-type sensors (Cantherm - MF51E103E3950, $10 \mathrm{~K} \Omega \pm 0.5 \%$ ). One thermistor was placed inside the test tube (Fig 1) for water temperature measurement (water sensor - WS). It was positioned and kept at the tube's center, with the use of a rigid wire spiral. Vertically, the sensor was positioned $2 \mathrm{~cm}$ away from the tube's lower extremity. The second sensor was placed along the tube's outer wall (external sensor - ES) and aligned with the water sensor. Finally, the third sensor was firmly placed, with adhesive tape, on the volunteer's skin (skin sensor - SS), at the 1/3 proximal, anteromedial part of the right forearm. A thin layer of thermal compound was used (Implastec - IPT300) to increase heat transfer of the second and third heat sensors and their respective measurement points.

The signals from the three sensors were filtered using a lower-pass of $5 \mathrm{~Hz}$. Digitalization was performed at a rate of 50 samples per second by using a USB-6211 board (16 bits) and LabView ${ }^{\circ}$ virtual instrumentation software, both produced by National Instruments ${ }^{\circ}$ (USA). A virtual instrument was especially constructed, which: shows real-time temperature curves of the three sensors; allows control of data saving to a computer's hard drive and generates sound signals (beeps) for stimulation cadence.

Prior to the beginning of the test, the volunteers were instructed to assess the sensation and to answer the following questions: $[\mathrm{A}]$ at the end of each session, whether the 4 stimuli had a similar or different intensity, and, if different, which one was the most intense; [B] at the end of the experiment, what was the difference in the perception of the stimuli between the three sessions.

\section{RESULTS}

In Fig 2, charts are presented with the average temperatures for each of the three sensors, as well as the beep signal for each session.

\section{Water temperature}

Water temperature, at the beginning of each session (t1), was measured at $45.5 \pm 0.3^{\circ} \mathrm{C}$. The cooling process was approximately linear, at the rate of $-1.28 \pm 0.10^{\circ} \mathrm{C} /$ min. There were small variations in the temperature of the water between the beginning and the end of each stimulus, the largest of them being $-0.3 \pm 0.06^{\circ} \mathrm{C}$, in session $\mathrm{S} 10$, and the smallest one $-0.04 \pm 0.05^{\circ} \mathrm{C}$, in session 
Table 1. Water temperature measurement.

\begin{tabular}{|c|c|c|c|c|c|c|c|c|c|}
\hline & \multirow[b]{2}{*}{ Water sensor } & \multicolumn{2}{|c|}{ Stimulus $1\left({ }^{\circ} \mathrm{C}\right)$} & \multicolumn{2}{|c|}{ Stimulus $2\left({ }^{\circ} \mathrm{C}\right)$} & \multicolumn{2}{|c|}{ Stimulus $3\left({ }^{\circ} \mathrm{C}\right)$} & \multicolumn{2}{|c|}{ Stimulus $4\left({ }^{\circ} \mathrm{C}\right)$} \\
\hline & & Begin (t1) & End (t2) & Begin (t3) & End (t4) & Begin (t5) & End (t6) & $\operatorname{Begin}(\mathrm{t} 7)$ & End (t8) \\
\hline \multirow[t]{3}{*}{ S2 } & Mean \pm S.D. & $45.6 \pm 0.29$ & $45.5 \pm 0.27$ & $45.4 \pm 0.28$ & $45.4 \pm 0.28$ & $45.2 \pm 0.27$ & $45.2 \pm 0.27$ & $45.0 \pm 0.27$ & $45.0 \pm 0.26$ \\
\hline & Amplitute $=$ Tempend - Temp pegin & \multicolumn{2}{|c|}{$0.0 \pm 0.05$} & \multicolumn{2}{|c|}{$-0.1 \pm 0.01$} & \multicolumn{2}{|c|}{$-0.1 \pm 0.02$} & \multicolumn{2}{|c|}{$0.0 \pm 0.02$} \\
\hline & $\Delta \mathrm{Temp}=\mathrm{Temp}_{\mathrm{end}}-\mathrm{Temp}_{\mathrm{t} 1}$ & \multicolumn{2}{|c|}{$0.0 \pm 0.05$} & \multicolumn{2}{|c|}{$-0.2 \pm 0.04$} & \multicolumn{2}{|c|}{$-0.4 \pm 0.08$} & \multicolumn{2}{|c|}{$-0.6 \pm 0.11$} \\
\hline \multirow[t]{3}{*}{ S5 } & Mean \pm S.D. & $45.6 \pm 0.27$ & $45.5 \pm 0.29$ & $45.3 \pm 0.29$ & $45.2 \pm 0.30$ & $45.1 \pm 0.31$ & $44.9 \pm 0.32$ & $44.8 \pm 0.32$ & $44.6 \pm 0.33$ \\
\hline & Amplitute $=$ Temp $p_{\text {end }}-$ Temp $_{\text {begin }}$ & \multicolumn{2}{|c|}{$-0.1 \pm 0.03$} & \multicolumn{2}{|c|}{$-0.1 \pm 0.03$} & \multicolumn{2}{|c|}{$-0.1 \pm 0.03$} & \multicolumn{2}{|c|}{$-0.1 \pm 0.02$} \\
\hline & $\Delta \mathrm{Temp}=\mathrm{Temp}_{\mathrm{end}}-\mathrm{Temp}_{\mathrm{t} 1}$ & \multicolumn{2}{|c|}{$-0.1 \pm 0.03$} & \multicolumn{2}{|c|}{$-0.4 \pm 0.06$} & \multicolumn{2}{|c|}{$-0.7 \pm 0.10$} & \multicolumn{2}{|c|}{$-0.9 \pm 0.14$} \\
\hline \multirow[t]{3}{*}{ S10 } & Mean \pm S.D. & $45.5 \pm 0.22$ & $45.2 \pm 0.23$ & $45.1 \pm 0.25$ & $44.8 \pm 0.29$ & $44.6 \pm 0.31$ & $44.4 \pm 0.35$ & $44.2 \pm 0.37$ & $44.0 \pm 0.39$ \\
\hline & Amplitute $=$ Tempend $_{\text {e }}-$ Tempegin $_{\text {beg }}$ & \multicolumn{2}{|c|}{$-0.3 \pm 0.06$} & \multicolumn{2}{|c|}{$-0.3 \pm 0.00$} & \multicolumn{2}{|c|}{$-0.3 \pm 0.06$} & \multicolumn{2}{|c|}{$-0.2 \pm 0.04$} \\
\hline & $\Delta T e m p=T_{e m p} p_{\text {end }}-T_{e m p} p_{t}$ & \multicolumn{2}{|c|}{$-0.3 \pm 0.06$} & \multicolumn{2}{|c|}{$-0.7 \pm 0.14$} & \multicolumn{2}{|c|}{$-1.1 \pm 0.20$} & \multicolumn{2}{|c|}{$-1.5 \pm 0.25$} \\
\hline
\end{tabular}

S2: session two seconds; S5: session five seconds; S10: session ten seconds.
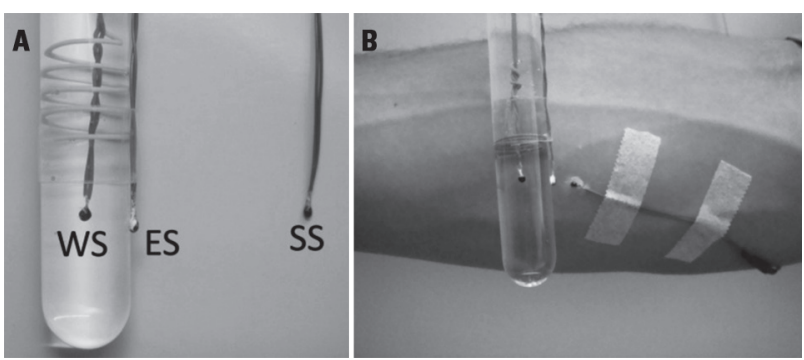

Fig 1. Temperature sensors $[A]$ their identification and $[B]$ their positioning for stimulation. WS: water sensor; ES: external sensor; SS: skin sensor.

S2, as expected (Table 1). However, in the time interval comprised between the first and the last stimulus ( $\mathrm{t} 1$ to t8), the water temperature variation was measured at $-0.6 \pm 0.11^{\circ} \mathrm{C}$ during session $\mathrm{S} 2,-0.9 \pm 0.14^{\circ} \mathrm{C}$ during session $\mathrm{S} 5$, and $-1.5 \pm 0.25^{\circ} \mathrm{C}$ during session $\mathrm{S} 10$.

\section{Tube's outer wall temperature}

At the beginning of the stimuli (instant $\mathrm{t} 1$ ), it was noted that the temperature of the tube's outer wall was of $41.3 \pm 0.69^{\circ} \mathrm{C}$. Such temperature was always lower $\left(-4.3 \pm 0.6^{\circ} \mathrm{C}\right)$ than the water's (Fig 2). In addition, when the temperatures at the initial instant (t1) and at the final instant of each stimulus $\left(\Delta \mathrm{Temp}=\mathrm{Temp} \mathrm{end}_{\mathrm{T}}-\mathrm{Temp}_{\mathrm{t} 1}\right)$ were compared, there was a noticeable decrease in the initial temperatures and increase in the final temperatures for sessions S5 and S10. For session S2, however, there was a decrease in the initial and final values. Such types of behavior produced a decreasing pattern for temperature variation (Table 2).

The magnitude of the tube's temperature variation during the first stimulus $\left(\mid\right.$ Amplitude $=$ Temp $_{\mathrm{t} 2}-$ $\left.\mathrm{Temp}_{\mathrm{t} 1} \mid\right)$ was significant, and considerably larger than that of the subsequent stimuli. That magnitude, as ex-
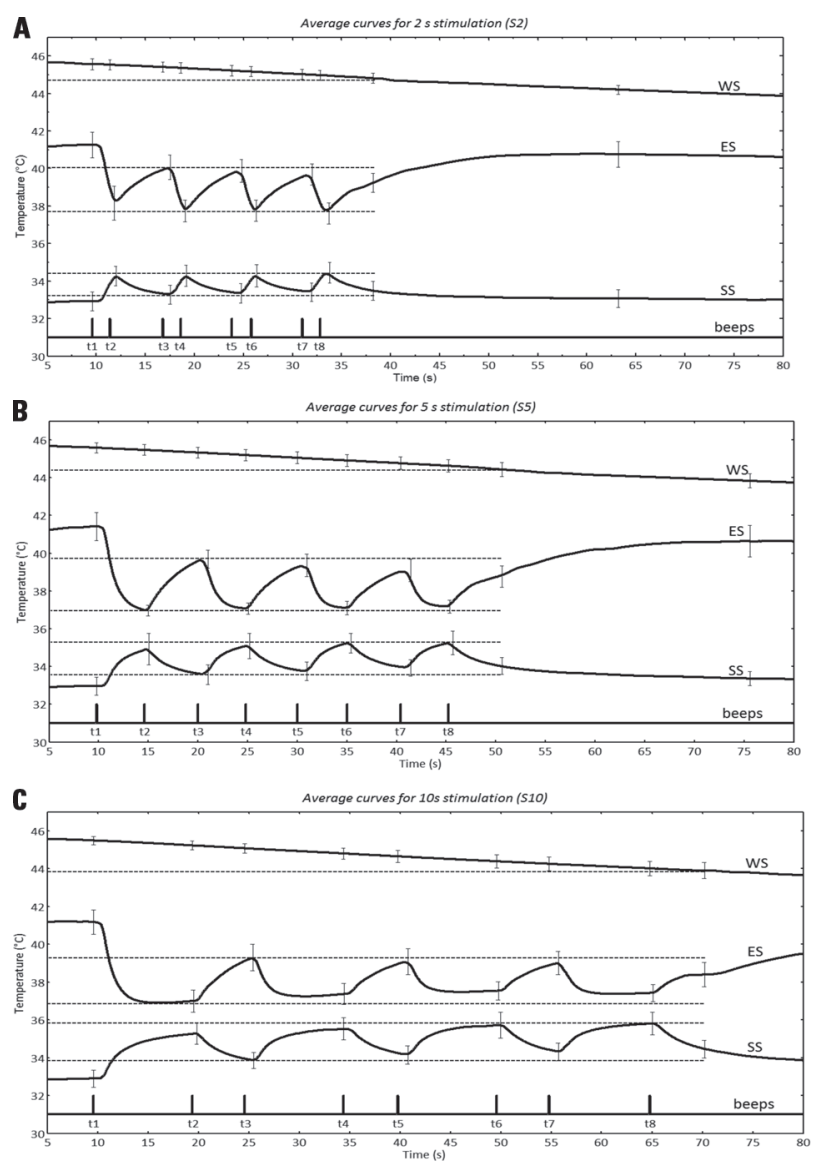

Fig 2. Temperature curves (average and standard deviation) for session: [A] S2; [B] S5 and [C] S10. WS: water sensor; ES: external sensor; SS: skin sensor; Beeps: stimulus starting at (t1, t3, t5, t7) and ending at $(t 2, t 4, t 6, t 8)$ respectively.

pected, increased with stimulation time, being measured, for session $\mathrm{S} 2$, at $3.1 \pm 0.68^{\circ} \mathrm{C}$ in the first stimulus and at $2.3 \pm 0.34^{\circ} \mathrm{C}$ in the second one. For session $\mathrm{S} 5$, the magnitude decreased from $4.4 \pm 0.85^{\circ} \mathrm{C}$ to $2.6 \pm 0.63^{\circ} \mathrm{C}$, and, for session $\mathrm{S} 10$, from $4.2 \pm 0.79^{\circ} \mathrm{C}$ to $1.9 \pm 0.61^{\circ} \mathrm{C}$. 
Table 2. Tube outer temperature measurements.

\begin{tabular}{|c|c|c|c|c|c|c|c|c|c|}
\hline & \multirow[b]{2}{*}{ External sensor } & \multicolumn{2}{|c|}{ Stimulus $1\left({ }^{\circ} \mathrm{C}\right)$} & \multicolumn{2}{|c|}{ Stimulus $2\left({ }^{\circ} \mathrm{C}\right)$} & \multicolumn{2}{|c|}{ Stimulus $3\left({ }^{\circ} \mathrm{C}\right)$} & \multicolumn{2}{|c|}{ Stimulus $4\left({ }^{\circ} \mathrm{C}\right)$} \\
\hline & & Begin (t1) & End (t2) & Begin (t3) & End (t4) & Begin $(t 5)$ & End (t6) & Begin (t7) & End (t8) \\
\hline \multirow[t]{3}{*}{ S2 } & Mean \pm S.D. & $41.3 \pm 0.70$ & $38.2 \pm 0.91$ & $40.1 \pm 0.66$ & $37.8 \pm 0.58$ & $39.9 \pm 0.62$ & $37.8 \pm 0.56$ & $39.7 \pm 0.57$ & $37.6 \pm 0.57$ \\
\hline & Amplitute $=$ Temp $_{\text {end }}-$ Temp pegin $_{\text {}}$ & \multicolumn{2}{|c|}{$-3.1 \pm 0.68$} & \multicolumn{2}{|c|}{$-2.3 \pm 0.34$} & \multicolumn{2}{|c|}{$-2.1 \pm 0.38$} & \multicolumn{2}{|c|}{$-2.1 \pm 0.35$} \\
\hline & $\Delta \mathrm{Temp}=\mathrm{Temp}_{\mathrm{end}}-\mathrm{Temp}_{\mathrm{t} 1}$ & \multicolumn{2}{|c|}{$-3.1 \pm 0.68$} & \multicolumn{2}{|c|}{$-3.5 \pm 0.72$} & \multicolumn{2}{|c|}{$-3.5 \pm 0.74$} & \multicolumn{2}{|c|}{$-3.6 \pm 0.70$} \\
\hline \multirow[t]{3}{*}{ S5 } & Mean \pm S.D. & $41.4 \pm 0.74$ & $37.0 \pm 0.28$ & $39.7 \pm 0.48$ & $37.1 \pm 0.30$ & $39.4 \pm 0.59$ & $37.1 \pm 0.35$ & $39.1 \pm 0.59$ & $37.2 \pm 0.35$ \\
\hline & Amplitute $=$ Temp $_{\text {end }}-$ Temp pegin $_{\text {b }}$ & \multicolumn{2}{|c|}{$-4.4 \pm 0.85$} & \multicolumn{2}{|c|}{$-2.6 \pm 0.63$} & \multicolumn{2}{|c|}{$-2.3 \pm 0.68$} & \multicolumn{2}{|c|}{$-1.9 \pm 0.55$} \\
\hline & $\Delta \mathrm{Temp}=\mathrm{Temp}_{\mathrm{end}}-\mathrm{Temp}_{\mathrm{t} 1}$ & \multicolumn{2}{|c|}{$-4.4 \pm 0.85$} & \multicolumn{2}{|c|}{$-4.3 \pm 0.86$} & \multicolumn{2}{|c|}{$-4.3 \pm 0.86$} & \multicolumn{2}{|c|}{$-4.2 \pm 0.73$} \\
\hline \multirow[t]{3}{*}{ S10 } & Mean \pm S.D. & $41.2 \pm 0.65$ & $37.0 \pm 0.60$ & $39.3 \pm 0.69$ & $37.4 \pm 0.56$ & $39.1 \pm 0.68$ & $37.5 \pm 0.49$ & $39.0 \pm 0.61$ & $37.4 \pm 0.45$ \\
\hline & Amplitute $=$ Temp $_{\text {end }}-$ Temp $_{\text {begin }}$ & \multicolumn{2}{|c|}{$-4.2 \pm 0.79$} & \multicolumn{2}{|c|}{$-1.9 \pm 0.61$} & \multicolumn{2}{|c|}{$-1.6 \pm 0.64$} & \multicolumn{2}{|c|}{$-1.6 \pm 0.61$} \\
\hline & $\Delta \mathrm{Temp}=\mathrm{Temp}_{\mathrm{end}}-\mathrm{Temp}_{\mathrm{t} \mathrm{1}}$ & \multicolumn{2}{|c|}{$-4.2 \pm 0.79$} & \multicolumn{2}{|c|}{$-3.8 \pm 0.78$} & \multicolumn{2}{|c|}{$-3.6 \pm 0.69$} & \multicolumn{2}{|c|}{$-3.7 \pm 0.50$} \\
\hline
\end{tabular}

S2: session two seconds; S5: session five seconds; S10: session ten seconds.

Table 3. Skin temperature measurements.

\begin{tabular}{|c|c|c|c|c|c|c|c|c|c|}
\hline & \multirow[b]{2}{*}{ Skin sensor } & \multicolumn{2}{|c|}{ Stimulus $1\left({ }^{\circ} \mathrm{C}\right)$} & \multicolumn{2}{|c|}{ Stimulus $2\left({ }^{\circ} \mathrm{C}\right)$} & \multicolumn{2}{|c|}{ Stimulus $3\left({ }^{\circ} \mathrm{C}\right)$} & \multicolumn{2}{|c|}{ Stimulus $4\left({ }^{\circ} \mathrm{C}\right)$} \\
\hline & & Begin (t1) & End (t2) & Begin (t3) & End $(t 4)$ & Begin (t5) & End (t6) & Begin (t7) & End (t8) \\
\hline \multirow[t]{3}{*}{ S2 } & Mean $\pm S . D$. & $32.9 \pm 0.50$ & $34.3 \pm 0.51$ & $33.3 \pm 0.50$ & $34.3 \pm 0.56$ & $33.3 \pm 0.52$ & $34.3 \pm 0.61$ & $33.4 \pm 0.50$ & $34.5 \pm 0.55$ \\
\hline & Amplitute $=$ Tempend - Temp $_{\text {begin }}$ & \multicolumn{2}{|c|}{$1.4 \pm 0.42$} & \multicolumn{2}{|c|}{$1.0 \pm 0.22$} & \multicolumn{2}{|c|}{$0.9 \pm 0.27$} & \multicolumn{2}{|c|}{$1.0 \pm 0.24$} \\
\hline & $\Delta \operatorname{Temp}=\operatorname{Temp}_{\mathrm{end}}-\mathrm{Temp}_{\mathrm{t} 1}$ & \multicolumn{2}{|c|}{$1.4 \pm 0.42$} & \multicolumn{2}{|c|}{$1.4 \pm 0.40$} & \multicolumn{2}{|c|}{$1.4 \pm 0.35$} & \multicolumn{2}{|c|}{$1.5 \pm 0.37$} \\
\hline \multirow[t]{3}{*}{ S5 } & Mean \pm S.D. & $33.0 \pm 0.47$ & $34.9 \pm 0.82$ & $33.6 \pm 0.53$ & $35.1 \pm 0.67$ & $33.7 \pm 0.49$ & $35.3 \pm 0.52$ & $33.9 \pm 0.44$ & $35.3 \pm 0.62$ \\
\hline & Amplitute $=$ Temp $_{\text {end }}-$ Temp $_{\text {begin }}$ & \multicolumn{2}{|c|}{$2.0 \pm 0.53$} & \multicolumn{2}{|c|}{$1.5 \pm 0.34$} & \multicolumn{2}{|c|}{$1.5 \pm 0.27$} & \multicolumn{2}{|c|}{$1.3 \pm 0.33$} \\
\hline & $\Delta \mathrm{Temp}=\mathrm{Temp}_{\mathrm{end}}-\mathrm{Temp}_{\mathrm{t} 1}$ & \multicolumn{2}{|c|}{$2.0 \pm 0.53$} & \multicolumn{2}{|c|}{$2.1 \pm 0.45$} & \multicolumn{2}{|c|}{$2.3 \pm 0.34$} & \multicolumn{2}{|c|}{$2.3 \pm 0.53$} \\
\hline \multirow[t]{3}{*}{ S10 } & Mean $\pm S . D$. & $32.9 \pm 0.44$ & $35.3 \pm 0.57$ & $33.9 \pm 0.42$ & $35.5 \pm 0.58$ & $34.1 \pm 0.48$ & $35.7 \pm 0.68$ & $34.3 \pm 0.47$ & $35.8 \pm 0.60$ \\
\hline & Amplitute $=$ Temp $_{\text {end }}-$ Temp $_{\text {begin }}$ & \multicolumn{2}{|c|}{$2.4 \pm 0.61$} & \multicolumn{2}{|c|}{$1.7 \pm 0.33$} & \multicolumn{2}{|c|}{$1.6 \pm 0.44$} & \multicolumn{2}{|c|}{$1.5 \pm 0.28$} \\
\hline & $\Delta \mathrm{Temp}=\mathrm{Temp}_{\mathrm{end}}-\mathrm{Temp}_{\mathrm{t} 1}$ & \multicolumn{2}{|c|}{$2.4 \pm 0.61$} & \multicolumn{2}{|c|}{$2.6 \pm 0.53$} & \multicolumn{2}{|c|}{$2.8 \pm 0.70$} & \multicolumn{2}{|c|}{$2.9 \pm 0.65$} \\
\hline
\end{tabular}

S2: session two seconds; S5: session five seconds; S10: session ten seconds.

\section{Skin temperature}

At the beginning of the stimuli (t1), it was noted that the skin's temperature was of $32.9 \pm 0.46^{\circ} \mathrm{C}$, i.e., much lower $\left(-12.6 \pm 0.61^{\circ} \mathrm{C}\right)$ than the water's (Fig 2). The highest temperature of the skin reached $35.8 \pm 0.60^{\circ} \mathrm{C}$, at the end of session $\mathrm{S} 10$.

The magnitude of the skin's temperature variation during the first stimulus, as in the case of the tube's temperature, was considerably larger than that of the subsequent stimuli (Table 3). For session S2, the magnitude was measured at $1.4 \pm 0.42^{\circ} \mathrm{C}$ in the first stimulus and $1.0 \pm 0.22^{\circ} \mathrm{C}$ in the second one. For session $\mathrm{S} 5$, the magnitude decreased from $2.0 \pm 0.53^{\circ} \mathrm{C}$ to $1.5 \pm 0.34^{\circ} \mathrm{C}$ and, for session $\mathrm{S} 10$, from $2.4 \pm 0.61^{\circ} \mathrm{C}$ to $1.7 \pm 0.33^{\circ} \mathrm{C}$. In the subsequent stimuli, the difference between the magnitudes did not exceed $0.2^{\circ} \mathrm{C}$ for each session.

The temperature's behavior presented an increasing pattern, i. e., during the intervals between the stimuli (t2$\mathrm{t} 3$, t4- $\mathrm{t} 5$ and $\mathrm{t6}-\mathrm{t} 7$ ) the skin's temperature did not return to its initial (basal) value. Therefore, the skin's tempera- ture at the second stimulus' initial instant (t3) is higher than that of the first stimulus (t1) and so forth. Table 3 shows that the second stimulus presented a temperature increase of $0.4 \pm 0.18^{\circ} \mathrm{C}$ for session $\mathrm{S} 2,0.6 \pm 0.18^{\circ} \mathrm{C}$ for session $\mathrm{S} 5$ and $1.0 \pm 0.32^{\circ} \mathrm{C}$ for session $\mathrm{S} 10$.

\section{DISCUSSION}

The skin's thermoreceptors respond to temperature variations of the basal value (which, according to different authors, ranges from 32 to $35^{\circ} \mathrm{C}^{8-11}$ ). Such receptors show a higher response on the face of quick temperature variations, but also respond, with lower intensity, to constant or slow-varying temperatures. The receptors responsible for heat sensations respond almost proportionally to the skin's temperature increase over $29^{\circ} \mathrm{C}$, reaching a peak of activity when the temperature reaches $45^{\circ} \mathrm{C}$, and then decreasing as the temperature approaches $49^{\circ} \mathrm{C}^{9,10}$. According to the Brazilian Ministry of Health, the water temperature must not exceed $45^{\circ} \mathrm{C}$ in heat sensitivity tests, because a sensation of heat pain may be pro- 
duced, instead of warmth. In this study, carried out in a controlled environment, the temperatures of water, tube's outer surface and skin were determined.

The water temperature (from 45.5 to $44.0^{\circ} \mathrm{C}$ ) decreased almost linearly $\left(-1.28 \pm 0.10^{\circ} \mathrm{C} / \mathrm{min}\right)$ during the whole experiment. The temperature at the tube's outer surface (from 41.3 to $37.2^{\circ} \mathrm{C}$ ) was always lower than that of the water contained in the tube, and that difference is due to the glass' low thermal conductivity ${ }^{6}$.

There is a complementary behavioral relationship between the temperature of the tube's outer surface and the temperature measured on the skin when it gains heat, i. e., the temperature of the tube's outer surface decreases and the skin's temperature increases, though with different magnitudes. Such difference is due, mostly, to the fact that the skin's specific heat is about five times that of the glass ${ }^{6,12}$. Therefore, the highest temperature measured on the skin $\left(35.8^{\circ} \mathrm{C}\right)$, i. e., the stimulation temperature of the skin's receptors, was always lower than the temperature measured at the tube's outer surface (minimum $37.2^{\circ} \mathrm{C}$ ) and much lower than the water temperature (minimum $44.0^{\circ} \mathrm{C}$ ). Even though the water temperature $\left(45^{\circ} \mathrm{C}\right)$ is, in theory, able to stimulate warming fibers (C fibers), as well as nociceptors responsible for heat pain (A $\delta$ and $C$ fibers), this study revealed that the temperature range of the stimulus measured on the skin during the stimuli $\left(34.3\right.$ to $\left.35.8^{\circ} \mathrm{C}\right)$ is related to warming fibers $\left(29 \text { to } 45^{\circ} \mathrm{C}\right)^{9,13}$. One can note, by relating the data collected from the present study with the temperature values recommended by the Brazilian Ministry of Health for the assessment of leprosy patients, that the test tube method can be useful in the study of thermal sensitivity, because, in skin injuries, alterations begin in the heating and cooling sensations, progressing to pain sensations (hot and cold) and then to tactile sensitivity ${ }^{14-26}$. Therefore, in endemic areas, in the investigation of injuries, the test can be useful in the disease's early diagnosis.

During the intervals between the stimuli the skin's temperature did not return to its initial (basal) value, presenting, instead, a tendency to increase. In addition, the magnitude of the stimuli decreased during the session. Thus, the conditions of the second and subsequent stimuli are different from those of the first. Considering the three sessions, S2 presented the smallest temperature differences between the stimuli, and seems, therefore, to be the most appropriated duration for the stimuli.

In answer to question [A], at the end of each session, whether the 4 stimuli had a similar or different intensity, and, if different, which one was the most intense, 12 of the 14 volunteers reported that the first stimulus was more intense than the others and the sensation of warmth decreased in the subsequent stimuli, which was confirmed by the measurements of the skin's tempera- ture (Table 3). Two volunteers (one male and one female) affirmed not to notice any difference in stimuli intensity. In answer to question [B], at the end of the experiment, what was the difference in the perception of the stimuli between the three sessions, all volunteers reported that the thermal sensation in the four stimuli was better perceived for stimulation times of five and ten seconds. That observation suggests that the difference in magnitude between the first and second stimuli $\left(0.4^{\circ} \mathrm{C}\right)$, which occurred in S2, was not easily noticed, which confirms, from a qualitative standpoint, that stimuli of similar intensity occurred.

This test does not allow a quantification of the results, making it difficult to be compared with subsequent tests. Several factors interfere in its variability and repeatability, among which, the exact temperature of the water in the tubes, the amount of water, the glass' thickness, room temperature, the positioning of the tube and the pressure it exerts on the skin, as well as the time of contact between the tube and the skin. Therefore, it is recommended that such thermal tests be performed with stimulators under strict temperature control, to ensure greater dependability and repeatability to the thermal sensitivity test.

\section{REFERENCES}

1. Bacarelli R. Avaliação sensitiva na neuropatia hansênica. In: Duerksen F (Ed). Cirurgia reparadora e reabilitação em hanseníase. Greenville: ALM International; 1997:85-92.

2. Brasil, Ministério da Saúde, Secretaria de Políticas de Saúde, Departamento de Atenção Básica. Guia para o Controle da hanseníase. Brasília: Ministério da Saúde; 2002:19.

3. Brasil. Ministério da Saúde. Secretaria de Políticas de Saúde. Departamento de Atenção Básica. Hanseníase - Atividades de Controle e Manual de Procedimentos. Brasília: Ministério da Saúde; 2001:38-39.

4. Brasil, Ministério da Saúde, Secretaria de Políticas de Saúde, Departamento de Atenção Básica. Vigilância em Saúde: Dengue, Esquistossomose, Hanseníase, Malária, Tracoma e Tuberculose - 2 ed. Brasília: Ministério da Saúde; 2008:71.

5. Castro IM. Um instrumento para investigação da sensibilidade térmica da pele. Hansen Int 1978;3:165-167.

6. Jacobsen R, Lemmon EW, Penoncello SG, Shan Z, Wright NT. Thermophysical Properties of Fluids. In: Bejan A, Kraus AD (Eds). Heat transfer handbook. $10^{\text {th }}$ ed. New Jersey: John Wiley \& Sons; 2003:134-139.

7. Neto EA. Prova do éter em hansenologia. Hansenologia Internationalis 1983;8:46-53.

8. Gardner EP, Martin JH, Jessell TM. The Bodily Senses. In: Kandel E, Schwartz J, Jessell T (Eds). Principles of Neural Science. 4th ed. New York: McGrawHill Medical; 2000:441-443.

9. Smith C. Biology of Sensory Systems. 2 ed. West Sussex, UK: John Wiley \& Sons, Ltd; 2009:415-421.

10. Guyton AC, Hall JE. Textbook of Medical Physiology. 11 ed. Philadelphia, Pennsylvania: Saunders; 2005:607-609.

11. Jones $L$, Berris $M$. The psychophysics of temperature perception and thermal-interface design. Proceedings 10th Symposium on Haptic Interfaces for Virtual Environment and Teleoperator Systems. 2002:137-142.

12. Xu F, Seffen K, Lu T. Non-Fourier analysis of skin biothermomechanics. Int J Heat Mass Transf 2007;51:2237-2259.

13. Kálmán M, Csillag A. The Skin and Other Diffuse Sensory Systems. Atlas of the Sensory Organs: Functional and Clinical Anatomy. $1^{\text {st }}$ ed. Totowa, New Jersey: Humana Press 2005:199-200.

14. Shetty $V$, Antia N, Jacobs J. The pathology of early leprous neuropathy. J Neurol Sci 1988:1-3:115-131. 
15. Saunderson P, Groenen G. Which physical signs help most in the diagnosis of leprosy? A proposal based on experience in the AMFES project, ALERT, Ethiopia. Lepr Rev 2000;1:34-42.

16. Singh G, Tutakne MA, Tiwari VD, Dutta RK. Quantification of thermal sensory loss in follow up of progress in leprosy. Indian J Lepr 1985;4:790-795.

17. Sirumban P, Kumar A, Durai V, Neelan PN. Diagnostic value of cardinal signs/symptoms in paucibacillary leprosy. Indian J Lepr 1988;2:207-214.

18. Srinivasan H, Stumpe B. Leprosy diagnosis: a device for testing the thermal sensibility of skin lesions in the field. Bull WHO 1989;6:635-641.

19. Tutakne MA, Tiwari VD, Chakrabarty N, Gupta CM. Quantification of thermal sensory perception in leprosy (a preliminary report). Indian J Lepr 1985;2:360-363.

20. Villarroel MF, Orsini MBP. Impaired warm and cold perception thresholds in leprosy skin lesions. Lepr Rev 2007;2:102-109.
21. Santiago S, Ferrer T, Espinosa ML. Neurophysiological studies of thin myelinated (A delta) and unmyelinated (C) fibers: application to peripheral neuropathies. Neurophysiol Clin 2000;30:27-42.

22. Jain GL, Pasricha JS, Guha SK. Minimum temperature felt as hot (MTH) a new concept for grading the loss of temperature sensation in leprosy patients. Int J Lepr Other Mycobact Dis 1985;53:206-210.

23. Natrajan M, Katoch K, Katoch VM. Patients presenting with defined areas of sensory loss-a preliminary study. Indian J Lepr 2001;1:17-26.

24. Ooi WW, Srinivasan J. Leprosy and the peripheral nervous system: basic and clinical aspects. Muscle Nerve 2004;4:393-409.

25. Ramesh V, Saxena V, Misra RS. How to detect leprosy in some patients with only localized sensory loss. Lepr Rev 1990;1:79-80.

26. Pfaltzgraff RE, Bryceson A. Clinical Leprosy. In: Hastings RC (Ed). Leprosy. 1st ed. New York: Churchill Livingstone; 1985:134-176. 